\title{
The Effectiveness of Hot Compress toward Pain Reduction Due To Phlebitis Caused By Intravenous Line Set Up In Malang and Ponorogo, East Java-Indonesia
}

\author{
Nurul Sriwahyuni, Tri Johan Agus Yuswanto \\ Faculty Health Science, University Muhammadiyah Ponorogo ; Health Polytechnic of Malang, Republic of \\ Indonesia
}

\begin{abstract}
Hot compress is an action to reduce pain by providing heat energy through conduction process. Phlebitis is a vein wall inflammation, which is characterized by pain, redness and sometimes local swelling. Phlebitis can be treated by pharmacological and non-pharmacological therapies. Non-pharmacological therapies that can be conducted including the provision of a hot compress. The purpose of this study was to identify the level of pain before and after a hot compress treatment and to determine the effectiveness of hot compresses to decrease phlebitis pain due to intravenous line set up. This study was conducted in two phases which consists of a case study with an observational participative design which was held in Malang and a quasi-experimental design with one group pre - post experimental method which was held in Ponorogo, with a sample comprising of 2 study subjects and 20 respondents who were obtained by using consecutive sampling. The results showed that there were faster changes when Bourbonais pain scale was used to measure the pain felt by the client after hot compress and the changes became slower when there was no hot compress with a twoday control, a decrease in pain levels between before treatment (pre-test) and after treatment (post-test.). It was also discovered that the provision of a hot compress effectively reduce pain caused by phlebitis after intravenaline set up. (Wilcoxon Signed Ranks Test $P=0.000$ and $Z=-3.874$ ). It is recommended to the hospital to socialize and intensively implemented this technique considering that this technique is cheap, easy to implement and with no side effects.
\end{abstract}

Keywords: intravenous line, phlebitis pain, hot compress

\section{Introduction}

Clients with serious illnesses need to be treated and observed routinely by the medical team which makes them hospitalized. One of the treatments for the inpatients is the intravenous line set up, which can be used to treat a variety of conditions which includes clients intake of intravenous solution, blood products, drugs and parenteral nutrition. The problem which often occurs as a result of intravenous therapy is venipuncture complications, such as phlebitis.

Phlebitis is a vein wall inflammation, which is characterized by pain sensation, redness and sometimes local swelling. Phlebitis can be treated with pharmacological and non-pharmacological therapies. Nonpharmacological therapies that can be conducted including the provision of a hot compress.

Hot compress is an action to reduce pain by providing thermal energy through the process of conduction, where the heat can cause vasodilation (widening of blood vessels) thereby it can increase oxygen intake, nutrients and blood leukocytes leading to body tissues. Some positive impacts due to the implementation of this treatment are that it can decrease inflammation, decrease muscle stiffness and pain and accelerate soft tissues healing. Based on the facts above, the writer would like to find out the effectiveness of the hot compress to decrease phlebitis pain due to intravenous line set up.

Pain is a discomfort or unpleasant season, whether it is mild or severe, it is an important sign of the presence of physiological disorders. Pain is a subjective experience, in which it follows what is being said and felt the client. In general, a pain stimulus is caused by several things, some of them are tissue damage, muscle contractions or spasms that cause ischemic type pain and increasing demand on limited blood supply, such as what is caused by vascular suppression. There are some factors affecting pain feeling, they are the age and experience of previous pain, sex and anxiety. The intensity of the pain can be determined in various ways, one of them is by interview.

\section{General Objective}

In general, the objective of this study was to determine the effectiveness of hot compresses to the decline of phlebitis pain due to intravenous line set up. 


\section{Specific Objective}

More specifically, this study aimed to identify the level of phlebitis pain caused by intravenous line set up line before and after its administration of hot compress treatment and to identify the effectiveness of hot compress to decrease phlebitis pain due to intravenous line set up.

\section{The advantage of the study}

1. For Community

The community can get more information about the benefits of a hot compress for reducing phlebitis pain and they can independently conduct the treatment to relieve the pain.

2. For the Development of Science and Technology of Nursing

a. As the application of existing theories about the effectiveness of hot compress provision to decrease pain in providing nursing care to clients who received intravenous therapy and experiencing phlebitis.

b. As one of the resources for case study researchers on nursing field about the effectiveness of hot compresses to decrease phlebitis pain. In the future, it is expected that it can improve of science and technology of nursing.

3. For the Researcher

To gain experience, especially on case studies on giving a hot compress to reduce pain due to phlebitis on clients who received intravenous therapy

\section{a. Design:}

\section{Method}

This study was consisted of 2 (two) stages, the first stage was a case study an participative observational study design conducted in Malang and Phase 2 (two) was with a quasi-experimental one group pre method - post experimental design conducted in Ponorogo.

\section{b. Research sample}

The subjects of the study in the case study was 2 inpatient clients in one of the hospitals in Malang. The number of respondents in the quasi-experimental study were 20 clients who experienced phlebitis problems due to the intravenous line set up in Ponorogo hospital.

\section{c. Data analysis}

The data obtained were analyzed with descriptive statistics presented in a narrative form and to determine the effectiveness of hot compresses to decrease phlebitis pain caused by the intravenous line set up, the writer used Wilcoxon Signed Rank Test.

The result of the 1st Stage of Study

\section{Results \& Discussion}

With a correct way in giving hot compress treatment, there will be a process of vasodilation of blood vessels, so that blood flow can bring metabolism results faster toward the inflamed areas so that the cells will recover soon which means the pain can be reduced faster too.

\section{The result of the 2nd Stage of Study}

a. Univariate analysis

1. Pain Level of respondents before treatment (pre-test) and after treatment (post-test)

Based on the measurements using Bourbonais Scale, the respondents perception of pain before and after treatment were as follow:

Table 1: Frequency Distribution of the comparison of respondents' level of pain before and after treatment

\begin{tabular}{|c|c|c|c|c|c|}
\hline \multirow[t]{2}{*}{ Pain level } & \multirow[t]{2}{*}{ Scale } & \multicolumn{2}{|l|}{ Before } & \multicolumn{2}{|l|}{ After } \\
\hline & & $\begin{array}{l}\text { Number of } \\
\text { resp. }\end{array}$ & $(\%)$ & $\begin{array}{l}\text { Number of } \\
\text { resp. }\end{array}$ & $(\%)$ \\
\hline No pain & 0 & 0 & $0 \%$ & 0 & $0 \%$ \\
\hline Mild pain & $1-3$ & 0 & $0 \%$ & 7 & $35 \%$ \\
\hline Moderate pain & $4-6$ & 18 & $90 \%$ & 13 & $65 \%$ \\
\hline Severe pain & $7-9$ & 2 & $10 \%$ & 0 & $0 \%$ \\
\hline Very severe pain/panicky & 10 & 0 & $0 \%$ & 0 & $0 \%$ \\
\hline
\end{tabular}

It can be seen from table 1 above that the level of pain before treatment (pre-test) were that 18 people (90\%) experienced mild pain and 2 people (10\%) experienced severe pain. After treatment (post-test), 7 people (35\%) experienced mild pain and 13 people (65\%) experienced moderate pain.

Various factors can affect the level of pain including the subject's age. In table 1, most of the subjects were at the age of 21-30 years ( 7 respondents $=35 \%$ ). Pain tolerance will continue to increase in accordance with 
the age. As someone gets older, the understanding and prevention efforts against pain will increase. In this study, it can be proven that respondents No. 9, 12, and 15 showed smaller perception of pain than the other respondents, as can be seen in Appendix 6. A person who often experiences pain will be more tolerant to pain than someone who rarely experiences pain. This behavior is often based on experience or trial and error (Brunner and Suddart, 2001: 217). This is also consistent with the opinion of Richard Sternbach (1989) in Fundamentals of Nursing (Kozier, 1995), who states that pain is something abstract that is related to the individual nature of sensation, or it is a sign that shows damage on body tissues and is a pattern of response to protect the organism from harm.

Another factor affecting the perception of pain is gender. Male tends to be more tolerant than female in response to pain (Leibeskind, 1991: 214). It can also be proven in this study that from 8 male respondents who perceived all pain experienced moderate pain. While from 12 female respondents, 10 respondents perceived moderate pain and 2 respondents experienced severe pain, as can be seen in Table 4. This is in line with the opinion of Priharjo, 1995 which states that pain is an either mild or severe discomfort or unpleasant feeling which becomes a sign essential to the existence of a physiological disorder and is a subjective experience.

\section{b. Bivariate analysis}

Wilcoxon Signed Rank Test.

Table 2. The Result of the test for measuring the effectiveness of a hot compress to decrease pain

\begin{tabular}{|l|l|}
\hline \multicolumn{1}{c|}{ Statistical test } \\
\hline & $\begin{array}{l}\text { Pain level before treatment-pain level after } \\
\text { treatment }\end{array}$ \\
\hline $\begin{array}{l}\text { Asymp. Sig. } \\
\text { (2-tailed) }\end{array}$ & $-3.874^{\mathrm{a}}$ \\
& .000 \\
\hline
\end{tabular}

The effectiveness of hot compress can be indicated by a 2-tailed asymptotically significant $\mathrm{P}$ value $=$ $0.000, \mathrm{Z}$ calculation $=-3.874, \mathrm{t}=2$ and Ttable $=52-158$. Because Tcalculation is not bigger than Ttable, then the null hypothesis is rejected with $\alpha=0.05$. It means that from 20 respondents, there were 18 respondents $(90 \%)$ who experienced the decline in pain level. Therefore, it can be stated that hot compress effectively reduces pain.

This happened as a result of local hot compress administration on phlebitis which was causes vasodilatation process, because when phlebitis occurs, there are many damages on body tissues that requires a lot of nutrients and oxygenation to fix them. The provision of hot compress can improve blood circulation on the tissue, the distribution of acid and food material to disposed cells will be repaired and cell activity will increase. This will reduce the pain and will support the process of wound healing.

As for the 2 respondents who did not experience the decrease in pain level, it was informed that those two respondents were admitted to the hospital for the first time due to a traffic accident which caused fractures, so that the respondents felt anxious about the situation.

\section{Conclusion And Recommendation}

Conclusion

1. 18 respondents $(90 \%)$ experienced moderate pain, 2 respondents $(10 \%)$ experienced severe pain before treatment. While after treatment (post-test), it was found out that 7 respondents (35\%) experienced moderate pain, and 13 respondents experienced (35\%) mild pain.

2. Provision of hot compress is effective to reduce phlebitis pain decline due to the set up of intravenous line, which can be demonstrated by a significant value of two-tailed P asymptotically $=0.000$, it was also supported by the data from a total of 18 respondents $(90 \%)$ who showed the decrease in pain level, 2 respondents $(10 \%)$ did not get any decrease in the level of pain and no respondents expressed an increase in the level of pain after treatment (post-test).

\section{Recommendation}

Based on the results described above, the researcher gives some recommendations as follow:

1. Hospitals need socialization efforts and more intensive application of hot compresses considering that this technique is cheap, easy to implement and without any side effects.

2. Future researchers should make attempts to create a media or device that can maintain the stability of the temperature of the hot compress for a certain period of time. It is intended to get the results with more optimal level of accuracy.

3. There should be some efforts to improve the understanding of client's perception of the level of perceived pain, associated to Bourbonis scale. 
4. There should be more studies on other types of pain other than phlebitis pain.

\section{Acknowledgement}

Deep gratitude is extended to the Dean of the Medical Science Faculty, University of MuhammadiyahPonorogo, the Director of Health Polytechnic Republic of Indonesia in Malang, and especially to Anita Dewi Puspitosari.

\section{References}

[1]. Elkin J.M.C., 2000, "Nursing Intervention and Clinical Skills", $2^{\text {nd }}$ Eddition. Missouri: Mosby-Year Book Inc.

[2]. Fawcett, NJ., 1999, "Nursing Practice Hospital and Home the Adult", Churchill. Livingstone.

[3]. Gabriel, JF., 1998, "Fisika Kedokteran", Jakarta: EGC.

[4]. Hartono A (Penerjemah). Roper, N., 1996, "Prinsip-Prinsip Keperawatan”, Yogyakarta: Yayasan Esentia Medika: 61-67.

[5]. Ignatavicius, 1996, "Medical Surgical Nursing: A Nursing Process Approach", Philadelphia: W.B. Sunders Company.

[6]. Kozier, Barbara, 1995, "Fundamental of Nursing Concepts, Process and Practice", California: Addition-Wesley. Inc.

[7]. LaRocca. JC., 1998, “Terapi Intravena”, Edisi II. Jakarta: EGC.

[8]. Leibeskind, 2001, "Konsep dan Tantangan Dalam Penatalaksanaan Pasien”, Jakarta: EGC

[9]. Long, CB., 1991, "Perawatan Medikal Bedah (Suatu Pendekatan Proses Keperawatan)", Yayasan lkatan Alumni Pendidikan Keperawatan (Penerjemah). Bandung: YIAPK.

[10]. Long, CB., 1996, "Perawatan Medikal Bedah (Suatu Pendekatan Proses Keperawatan",. Yayasan lkatan Alumni Pendidikan Keperawatan (Penerjemah). Bandung: YIAPK.

[11]. Nettina, MS., 2002, "Pedoman Praktek Keperawatan", Jakarta: EGC.

[12]. Notoatmodjo, S., 2002, "Metodologi Penelitian Kesehatan”, Jakarta: Rineka Cipta,: 93.

[13]. Pooter Harry, 2000, "Perawatan Nyeri", Jakarta: EGC.

[14]. Priharjo, Robert, 1995, "Perawatan Nyeri Pemenuhan Kebutuhan Istirahat Pasien", Jakarta: EGC.

[15]. Rosdahl, CB., 1999, "Basic Nursing", $7^{\text {th }}$ Eddition, New York: Philadelphia: Lippincot.

[16]. Stevens P.J.M., 2000, "Ilmu Keperawatan (Verpleegkundige Zorg)”, Jilid I. Edisi 2. Jakarta: EGC.

[17]. Suddart Brunner, 1999, "Perawatan Nyeri”, Edisi II. Jakarta: EGC

[18]. Taylor, 1997, "Fundamental of Nursing, The Art and Science of Nursing Care", $3{ }^{\text {rd }}$ Eddition, New York: Philadelpia: Lippincot.

[19]. Wasito H., 1997, "Pengantar Metodologi Penelitian”, Buku Panduan Mahasiswa. Jakarta: Gramedia Pustaka. 